\title{
ANALISIS HIGHER ORDER THINKING SKILL (HOTS) SISWA MADRASAH IBTIDAIYAH DALAM MENYELESAIKAN SOAL BAHASA INDONESIA
}

\author{
Untung Setyo Aji \\ IAIN Purwokerto, Purwokerto, Indonesia \\ untung1411@gmail.com
}

\begin{abstract}
This research was conducted in order to describe the students' ability in higher order thinking (Higher Order Thinking Skill) as an indicator of learning success which is very important to do. One of the offers was to conduct research on student learning outcomes about what-based student learning outcomes assessment was HOTS and how to apply-based student learning outcomes assessments HOTS at Madrasah Ibtidaiyah which can be used to measure students' ability in higher order thinking (HOTS). The purpose of this study was to measure the extent to which students' ability to solve HOTS questions on the daily test assessment questions Thematic subject 7 sub-theme 3 learning 5 Indonesian language. The method used in this research was field research using a descriptive qualitative approach with content analysis techniques (content analysis). This study involved 14 fourth grade students of MI Muhammadiyah Beji subdistrict Kedungbanteng, Banyumas Regency. Data analysis was performed with item indicators HOTS consisting of levels C4 (analysis), C5 (assessing), and C6 (creating). Based on the results of the analysis, of the 4 test questions, questions number 1 and number 2 all students were able to answer as many as 14 students (100\%). Question number 3 students were able to answer as many as 12 students (85\%) and students answered briefly as many as 2 students (15\%). Question number 4 students were able to answer as many as 11 students (78\%), answered briefly as many as 2 students (14\%), and wrong answers were 1 student (8\%). So, overall it can be concluded that students 'high-order thinking skills have met the criteria HOTS but they are still not evenly distributed among all students, so it needs
\end{abstract}


to be improved again by strengthening students' understanding of higher-order thinking skills at levels C4, C5, and C6.

Keywords: Higher Order Thinking Skill; Students; Questions Indonesian Language.

\begin{abstract}
Abstrak
Penelitian ini dailakukan dalam rangka mengetahui gambaran kemampuan siswa dalam berpikir tingkat tinggi (Higher Order Thinking Skill) sebagai salah satu indikator keberhasilan pembelajaran yang begitu penting untuk dilakukan. Salah satu tawarannya adalah dengan melakukan penelitian terhadap hasil belajar siswa tentang apa itu penilaian hasil belajar siswa berbasis HOTS dan bagaimana penerapan penilaian hasil belajar siswa berbasis HOTS di Madrasah Ibtidaiyah yang mana dapat digunakan untuk mengukur kemampuan siswa dalam berpikir tingkat tinggi (HOTS). Tujuan dari penelitian ini adalah untuk mengukur sejauh mana kemampuan siswa dalam menyelesaikan soal HOTS pada soal penilaian ulangan harian mata pelajaran Tematik tema 7 subtema 3 pembelajaran 5 muatan Bahasa Indonesia. Metode yang digunakan dalam penelitian ini adalah penelitian lapangan (field research) menggunakan pendekatan kualitatif deskriptif dengan teknik analisis isi (content analysis). Penelitian ini melibatkan 14 siswa kelas IV MI Muhammadiyah Beji Kecamatan Kedungbanteng Kabupaten Banyumas. Analisis data dilakukan dengan indikator soal HOTS yang terdiri dari level C4 (analisis), C5 (menilai), dan C6 (mencipta). Berdasarkan hasil analisis, dari 4 soal uraian yang diujikan, soal nomor 1 dan nomor 2 semua siswa mampu menjawab sebanyak 14 siswa (100\%). Soal nomor 3 siswa mampu menjawab sebanyak 12 siswa (85\%) dan siswa menjawab dengan singkat sebanyak 2 siswa (15\%). Soal nomor 4 siswa mampu menjawab sebanyak 11 siswa (78\%), menjawab dengan singkat sebanyak 2 siswa (14\%), dan jawaban salah sebanyak 1 siswa (8\%). Jadi, secara keseluruhan dapat disimpulkan bahwa keterampilan berpikir tingkat tinggi siswa sudah memenuhi kriteria HOTS namun masih belum merata pada semua siswa, sehingga perlu ditingkatkan lagi dengan menguatkan pemahaman siswa pada keterampilan berpikir tingkat tinggi pada level C4, C5, dan C6.
\end{abstract}

Kata kunci: Higher Order Thinking Skill; Siswa; Soal Bahasa Indonesia. 


\section{A. Pendahuluan}

Pembelajaran dan penilaian berbasis keterampilan berpikir tingkat tinggi (Higher Order Thinking Skill) atau berpikir kritis sangat direkomendasikan dalam penyelenggaraan pendidikan yang memiliki mutu tinggi. Implementasi pembelajaran dan penilaian berbasis HOTS diharapkan mampu mencetak peserta didik yang bermutu dan berkompetensi tinggi dalam rangka menghadapi era persaingan bebas atau revolusi industry 4.0.

Pemerintah mengharapkan para peserta didik dapat mencapai berbagai kompetensi dengan penerapan HOTS atau keterampilan berpikir tingkat tinggi. Kompetensi tersebut meliputi: berpikir kritis (critical thinking), kreatif dan inovatif (creative and innovative), kemampuan berkomunikasi (communication skill), kemampuan bekerjasama (collaboration), dan kepercayaan diri (confidence). Lima hal ini yang menjadi target karakter peserta didik pada sistem evaluasi UN dan juga merupakan kecakapan pada abad 21 ini (DIKDAS, 2019).

Programme For International Student Assesment (PISA) masih menempatkan Keterampilan Berpikir Tingkat Tinggi (HOTS) peserta didik khususnya tingkat menengah di Indonesia masih dalam level yang lebih rendah, sementara Trends In International Mathematics And Science Study (TIMSS) pada tahun 2015 untuk kelas IV Sekolah Dasar, Indonesia menempati peringkat 4 terbawah dati 43 negara yang mengikuti TIMSS. Sekitar 75\% item yang diujikan dalam TIMSS telah diajarkan di kelas IV Sekolah Dasar (Mubarok, 2019, p. 217). Sehingga pemerintah Indonesia dalam hal ini standar Ujian Nasional (UN) harus ditingkatkan untuk mengejar ketertinggalan berdasarkan penelitian yang telah dilakukan oleh TIMSS (DIKDAS, 2019).

Dalam rangka menghadapi era revolusi pengetahuan seperti sekarang ini, apa yang harus dilakukan adalah merevolusi dalam cara mendidik. Dengan begitu maka perlu pembelajaran dan penilaian pembelajaran yang dirancang dengan baik oleh 
para pendidik (Helmawati, 2019, p. 17). Guru sebagai seorang pendidik hendaknya memahami benar fungsi dan tugasnya dalam membantu mencerdaskan anak bangsa.

Suyomukti menyatakan bahwa berpikir kritis merupakan sebuah skills cognitive yang memungkinkan seseorang menginvestasi sebuah situasi, masalah, pertanyaan, atau fenomena agar dapat membuat sebuah penilaian atau keputusan (Suyomukti, 2013, p. 54). Kemampuan berpikir kritis dan berpikir tingkat kreatif merupakan indikator kemampuan berpikir tingkat tinggi dimana berpikir kritis merupakan suatu proses berpikir tingkat tinggi dalam pembentukan konseptual peserta didik (Helmawati, 2019).

Arifin mendefinisikan penilaian sebagai suatu proses atau kegiatan yang sistematis dan berkesinambungan untuk mengumpulkan informasi tentang proses dan hasil belajar peserta didik dalam rangka membuat keputusan-keputusan berdasarkan kriteria dan pertimbangan tertentu. Keputusan yang dimaksud adalah keputusan tentang peserta didik, seperti nilai yang akan diberikan atau juga keputusan tentang kenaikan kelas atau kelulusan (Kunandar, 2014, p. 66).

Pada kurikulum 2013 terdapat penilaian yang harus dilaksanakan pada proses pembelajaran yaitu disebut penilaian. Penilaian tersebut mencakup dalam aspek penilaian spiritual ,aspek penilaian sikap sosial, aspek penilaian pengetahuan, dan aspek penilaian keterampilan yang menjadi dasar penilaian pada peserta didik (Lubis, 2019, p. 185).

Sudah semestinya pendidik dalam melakukan kegiatan pembelajaran selain persiapan pembelajaran yang matang, juga perlu menyiapkan penilaian pembelajaran yang terukur, agar apa yang diajarkan dalam pembelajaran dapat diterima dengan baik melalui penilaian pembelajaran dengan tingkat pemahaman yang bertingkat.

Secara umum, berdasarkan tingkat objektivitas penskoran, bentuk tes yang diberikan kepada siswa dibagi ke dalam dua jenis tes, 
yaitu tes objektif dan subjektif. Tes obektif meliputi tes menjodohkan, benar - salah, dan pilihan ganda. Sedangkan tes subjektif meliputi tes esei dan pertanyaan singkat (Djiwandono, 2011).

Berdasarkan pemaparan diatas, dapat diketahui bahwa untuk mengetahui keterampilan berpikir tingkat tinggi yang sesuai dengan dimensi pengetahuan peserta didik, dapat melalui penilaian yang disusun sesuai dimensi pengetahuan HOTS. Dengan begitu, hasil dari penyusunan penilaian pembelajaran berbasis HOTS dapat djjadikan acuan dalam mengukur keterampilan berpikir peserta didik khususnya dalam peneltian ini pada jenjang kelas IV pada mata pelajaran Bahasa Indonesia.

Secara tingkat kematangan berpikir, kelas IV merupakan awal siswa memasuki tingkatan kelas tinggi, sehingga kemampuan kognitif sudah dan bahkan mampu untuk berpikir secara sistematis dan mendalam. Mata pelajaran Bahasa Indonesia dipilih berdasarkan keluasan materi yang banyak melibatkan imajinasi siswa dalam mengerjakan soal-soal instrumen penilaian yang dirasa mampu meningkatkan secara maksimal terhadap keterampilan berpikir tingkat tinggi peserta didik.

Pada penelitian ini, penulis menitik beratkan pada kemampuan siswa dalam mengolah keterampilan berpikir tingkat tinggi (HOTS), sebagaimana penelitian yang dilakukan oleh Mufatihatut Taubah (Taubah, 2019) yang memaparkan Penilaian HOTS dan Penerapannya di SD MI. dengan metode penelitian lapangan, Taubah menjelaskan lebih lanjut dalam penerapannya, dibutuhkan seorang guru yang kreatif mengetahui isu-isu global sehingga menghasilkan kemampuan yang berbobot dalam penyusunan butir-butir soal yang digunakan dalam melakukan penilaian yang dilakukan oleh seorang guru.

Lain dengan penelitian yang dilakukan oleh Mahfud Nahrowi (Nahrowi, 2019), fokus untuk Mengembangkan Model Penilaian Autentik Dalam Pembelajaran Tematik Berbasis Higher Order Thinking Skill, menggunakan metode penelitian Research and Development ( $R \& D$ dengan mengambil salah satu 
Madrasah Ibtidaiyah di daerah Kudus kecamatan Gebog untuk mengembangkan model pembelajaran tersebut. Begitu juga dengan penelitian yang dilakukan Husni Mubarok (Mubarok, 2019) penelitiannya dalam Pembentukan Karakter Higher Order Thinking Skill Siswa Sekolah Dasar di Era Industri 4.0. Mubarok menyimpulkan bahwa terdapat muatan HOTS dalam proses pembentukan karakter peserta didik salah satunya melalui 4Cs (critical thinking, communication, collaboration, and creativity).

Secara keseluruhan, dari telaah jurnal hasil penelitian yang pernah dilakukan diatas, dapat ditarik garis besar bahwa keterampilan berpikir tingkat tinggi (higher order thinking skill) sangat dibutuhkan untuk membekali peserta didik dalam menghadapi era teknologi 4.0 mulai dari penerapannya dalam kegiatan pembelajaran sampai pada tingkat evaluasi hasil belajar peserta didik hingga membuat model pengembangan penilaian pembelajaran berbasis HOTS. Hanifah juga memberikan penguatan bahwa keterampilan berpikir tingkat tinggi sangat penting untuk diterapkan dan dikembangkan dalam pembelajaran. Jika siswa memiliki kemampuan berpikir tingkat tinggi, maka dalam pembelajaran pun akan mampu menggunakan cara pemecahan masalah dengan baik, tepat dan dengan percaya diri (Hanifah, 2019, p. 3).

Penelitian ini dilakukan bertujuan untuk mengukur seberapa efektif penggunaan evaluasi pembelajaran berbasis keterampilan berpikir tingkat tinggi (HOTS) peserta didik pada kelas IV di Madrasah Ibtidaiyah Muhammadiyah Beji Kecamatan Kedungbanteng Kabupaten Banyumas, dan seberapa besar kemampuan peserta didik dalam mengolah keterampilan berpikir tingkat tinggi dalam menyelesaiakn evaluasi pembelajaran. Penelitian ini mengkaji dan menganalisis keterampilan berpikir tingkat tinggi (HOTS) peserta didik dalam menyelesaikan soal evaluasi Bahasa Indonesia berbasis Higher Order Thinking Skill. 


\section{B. Pembahasan}

\section{Metode penelitian}

Dalam penelitian ini, metode yang digunakan adalah metode kualititatif jenis penelitiannya eksperimen dengan teknik analisis isi. Penelitian ini melibatkan satu kelas dengan jumlah laki-laki sebanyak 8 siswa dan perempuan sebanyak 6 siswi, sehingga total sebanyak 14 siswa kelas IV B di MI Muhammadiyah Beji kedungbanteng Kabupaten banyumas.

Materi pembelajaran yang diujikan meliputi (1) menemukan informasi penting dalam paragraf, (2) menuliskan ide pokok yang terdapat dalam paragraf, (3) merangkai ide pokok menjadi satu paragraf utuh, dan (4) membuat peta pikiran berdasarkan informasi penting yang sudah ditemukan. Keempat materi tersebut didistribusikan dalam 4 soal uraian.

Analisis data dilakukan dengan mengacu pada indikator keterampilan berpikir tingkat tinggi (HOTS) yang terdiri atas level analisis (C3), evaluasi (C4), dan mencipta (C6) dengan menggunakan metode analisis isi. Analisis ini merupakan suatu studi yang sifatnya analitik dengan menyajikan hasilnya dalam bentuk uraian naratif yang menjawab pertanyaan-pertanyaan penelitian. sehingga dari hasil analisis ini, dapat menggambarkan penilaian pembelajaran berbabsis HOTS yang sudah dilakukan (Hamzah, 2019, p. 29).

\section{Keterampilan Berpikir Tingkat Tinggi (HOTS) dan Penilaiannya}

Menurut Thomas dan Thorne sebagaimana dikutip oleh Nugroho, mendefinisikan Higher Order Thinking Skill adalah cara berpikir yang lebih tinggi daripada menghafalkan fakta, menemukan fakta, atau menerapkan peraturan, rumus, dan prosedur (Nugroho, 2019, p. 16). Barratt sebagaimana dikutip oleh Mubarok juga mendefinisikan Higher Order Thinking Skill (HOTS) adalah keterampilan berpikir tingkat tinggi dalam yang menuntut pemikiran secara kritis, kreatif, analisis terhadap informasi dan 
data dalam memecahkan permasalahan (Mubarok, 2019). Berpikir tingkat tinggi membutuhkan proses ketekunan, kedisiplinan diri, dan perhatian penuh dalam berpikir kritis dan kreatif.

Taksonomi Bloom disempurnakan oleh Andereson (Helmawati, 2019), membagi dimensi pengetahuan menjadi enam tahapan, meliputi: C1 mengingat, C2 memahami, C3 menerapkan, C4 menganalisis, C5 menilai, dan C6 mencipta. Dari keenam dimensi pengetahuan tersebut, C4-C6 merupakan dimensi pengetahuan HOTS. Sehingga pendidik harus memperhatikan tahapan tersebut dalam proses pembelajaran sampai pada penilaian peserta didik.

Tabel 1. Perbedaan Taksonomi Bloom dan Andersoon

\begin{tabular}{ccc} 
Taksonomi Bloom & Taksonomi \\
Pengetahuan & C1 & Mengingat \\
\hline Pemahaman & C2 & Memahami \\
\hline Penerapan & C3 & Menerapkan \\
\hline Analisis & C4 & Menganalisis \\
\hline Sintesis & C5 & Menilai \\
\hline Penilaian & C6 & Mencipta \\
\hline
\end{tabular}

Bloom membagi keterampilan menjadi dua bagian. Pertama, keterampilan tingkat rendah yang penting dalam proses pembelajaran, yaitu mengingat (remembering), memahami (understanding), dan menerapkan (applying), dan kedua, yang diklasifikasikan ke dalam keterampilan berpikir tingkat tinggi berupa keterampilan menganalisis (analysing), mengevaluasi (evaluating), dan mencipta (creating) (Mubarok 2019:219).

Keterampilan berpikir tingkat tinggi sangat erat kaitannya dengan dimensi pengetahuan, dimensi sikap, dan dimensi keterampilan. Bloom mengukur standar kompetensi lulusan melalui ketiga dimensi tersebut. Kompetensi lulusan merupakan kualifikasi penilaian kemampuan yang sesuai dengan standar nasional yang ditetapkan, sehingga dapat menentukan standar 
kriteria berpikir tingkat tinggi atau rendah berdasarkan konsep kompetensi yang dirancang. Demikian pula Anderson dan Karthwohl berpendapat bahwa dalam proses pembelajaran dan asesmen umumnya hanya melibatkan pada satu jenis proses kognitif saja yakni mengingat, sehingga disarankan untuk pembelajaran dan asesmen harus mencakup pada proses-proses kognitif lainnya (Anderson, Lorin W.. Karthwohl, 2014, p. 94).

Berdasarkan buku penilaian HOTS yang dikeluarkan oleh Kementerian Pendidikan dan Kebudayaan karakteristik HOTS dapat diuraikan sebagai berikut (1) Mengukur kemampuan berpikir tingkat tinggi, yaitu proses menganalisis, merefleksi, memberikan argumen (alasan), menerapkan konsep pada situasi berbeda, menyusun, menciptakan; (2) Bersifat divergen, memungkinkan peserta didik memberikan jawaban berbedabeda sesuai proses berpikir dan sudut pandang yang digunakan karena mengukur proses berpikir analitis, kritis, dan kreatif yang cenderung bersifat unik atau berbeda-beda responsnya bagi setiap individu; (3) Menggunakan multirepresentasi, yaitu secara umum tidak menyajikan semua informasi secara tersurat, tetapi memaksa peserta didik menggali sendiri informasi yang tersirat; (4) Berbasis permasalahan kontekstual, yaitu merupakan asesmen yang berbasis situasi nyata dalam kehidupan seharihari, di mana peserta didik diharapkan dapat menerapkan konsep-konsep pembelajaran di kelas untuk menyelesaikan masalah. Dalam pengertian tersebut termasuk pula bagaimana keterampilan peserta didik untuk menghubungkan (relate), menginterpretasikan (interprete), menerapkan (apply) dan mengintegrasikan (integrate) ilmu pengetahuan dalam pembelajaran di kelas untuk menyelesaikan permasalahan dalam konteks nyata; (5) Menggunakan bentuk soal beragam, yaitu soal yang beragam dalam sebuah perangkat tes (soal-soal HOTS) sebagaimana yang digunakan dalam PISA, bertujuan agar dapat memberikan informasi yang lebih rinci dan menyeluruh tentang kemampuan peserta tes (Khotimah, 2019, p. 88). 
HOTS merupakan cara berpikir pada tingkat yang lebih tinggi daripada memahami dan menghafalkan atau menceritakan kembali materi yang disampaikan oleh guru dalam kegiatan pembelajaran. Selanjutnya, Taubah membagi kemampuan HOTS yang harus dimiliki siswa menjadi 3 kemampuan, yaitu: (1) menganalisis, diartikan siswa memiliki kemampuan menspesifikasi aspek-aspek/ elemen, baik itu materi pembelajaran atau apapun, yang didapat dari proses pembelajaran, (2) mengevaluasi, diartikan siswa dapat mengambil keputusan sendiri tentang apa yang akan atau tidak dilakukan, dan (3) mengkreasi/mencipta, diartikan siswa dapat mengkreasi ide atau gagasannya sendiri (Taubah, 2019).

Kurikulum 2013 seiring dikembangkannya yang berkesinambungan dalam mempersiapkan peserta didik agar memiliki kemampuan dan kecakapan hidup sebagai pribadi dan warga negara yang beriman, produktif, kreatif, inovatif, dan afektif serta mampu berkontribusi pada kehidupan bermasyarakat, berbangsa, bernegara, dan peradaban dunia (Taubah, 2019). Selanjutnya, tugas guru dan lembaga sekolah adalah mengimplementasikan amanat kurikulum 2013 yang kritis, kreatif, dan inovatif (Salsabilla \& Zafi, 2020).

Setiap siswa tentunya memiliki keterampilan berpikir yang berbeda-beda pada setiap individunya, ada yang kreatif dan ada juga yang statis. Untuk dapat mengetahui kemampuan dalam olah pikir siswa, perlu dilakukan penilaian secara terukur melalui soalsoal yang sesuai dengan kriteria dan kaidah berpikir siswa sesuai kelas yang dijadikan eksperimen dalam penelitian.

Analisis keterampilan berpikir ini masuk dalam dimensi pengetahuan. Bagaimana siswa dapat mengoptimalkan pengetahuannya pada tingkat keterampilan berpikir tingkat tinggi meliputi menganalisis, menilai, dan mencipta. Dari dimensi pengetahuan ini, peneliti dapat menentukan sejauh mana siswa dapat mengolah keterampilan berpikit tingkat tinggi dalam menyelesaikan soal-soal berbasis HOTS (Zafi, 2020). 
Mata pembelajaran Bahasa Indonesia pada kelas IV Madrasah Ibtidaiyah, dalam cakupan ketercapaian hasil belajar banyak yang mengandung keterampilan dalam menganalisis, seperti tertuang dalam indikator hasil belajar meliputi (1) siswa dapat menemukan informasi penting dalam teks, (2) siswa dapat menemukan ide pokok yang terkandung dalam sebuah paragraf, (3) siswa dapat menuliskan kembali isi pokok paragraf menjadi satu paragraf yang utuh.

Dalam melakukan penilaian pembelajaran keterampilan berpikir tingkat tinggi, mula-mula dirancang langkah-langkah pembelajaran terlebih dahulu kemudian diterapkan di MI Muhammadiyah Beji Kecamatan Kedungbanteng Kabupaten Banyumas. Subjek penelitian ini melibatkan siswa kelas IV dengan jumlah 14 siswa yang terdiri dari 8 orang laki-laki dan 6 orang perempuan. Pembelajaran dilakukan didalam ruangan kelas.

Tahap pertama, pada kegiatan awal siswa diberikan penjelasan materi oleh guru mengenai materi yang akan menjadi topik pembahasan pada pembelajaran yang sedang dilakukan. Dengan strategi pembelajaran saintifik, agar pembelajaran tidak terpusat pada guru. Pada tahap kedua ini, masuk pada kegiatan eksplorasi. Siswa dibimbing oleh guru untuk mengidentifikasi teks yang terdapat dalam buku paket yang masing-masing dipegang oleh siswa. Pada tahapan ini, siswa diminta untuk membaca dan sekaligus menemukan informasi penting, ide pokok yang terdapat dalam teks cerita. Setelah mereka dapat menemukannya, selanjutnya siswa diminta untuk dapat menuliskan satu paragraf yang utuh berdasarkan teks cerita yang sudah mereka baca sebelumnya.

Pada tahap ketiga ini, setelah semuanya melakukan pembelajaran dengan tertib dan antusiasme yang tinggi, selanjutnya mereka diberikan soal yang menjadi bahan penilaian pada kegiatan pembelajaran ini. Dengan mandiri, siswa diarahkan untuk mengerjakan soal semaksimal mungkin. Tahap terakhir dari kegiatan pembelajaran ini dilakukan verifikasi dan klasifikasi terhadap data dari hasil evaluasi kegiatan pembelajaran yang telah dilakukan oleh siswa. 
Prosedur selanjutnya yaitu mengidentifikasi hasil penilaian siswa dengan urutan kegiatan mengolah, menganalisis, dan menginterpretasikan hasil penilaian sekaligus mengklasifikasikan kemampuan berpikir siswa berdasarkan tahapan berpikir tingkat rendah Lower order thinking skill (LOTS), berpikir tingkat sedang middle order thinking skill (MOTS), dan berpikir tingkat tinggi higher order thinking skill (HOTS).

\section{Kemampuan Siswa Dalam Menyelesaikan Soal HOTS}

Berdasarkan hasil pembelajaran dan analisis peneliti, mulai dari awal kegiatan pembelajaran sampai akhir pembelajaran siswa mengikuti dengan antusiasme yang cukup tinggi terhadap materi yang disajikan. Ketika guru menginstruksikan kepada siswa untuk menyebutkan informasi penting yang terdapat dalam teks cerita mereka semua menjawab dengan menyebutkan dengan lantang.

Hasil dari lembar penilaian yang telah dilakukan, hampir semua siswa mampu menjawab dengan kriteria mampu menganalisis, menilai dan mencipta. Maka dapat disimpulkan bahwa, siswa kelas IV MI Muhammadiyah Beji memiliki keterampilan berpikir tingkat tinggi (HOTS). Adapun hasil penilaian lembar kerja siswa dapat diuraikan sebagai berikut:

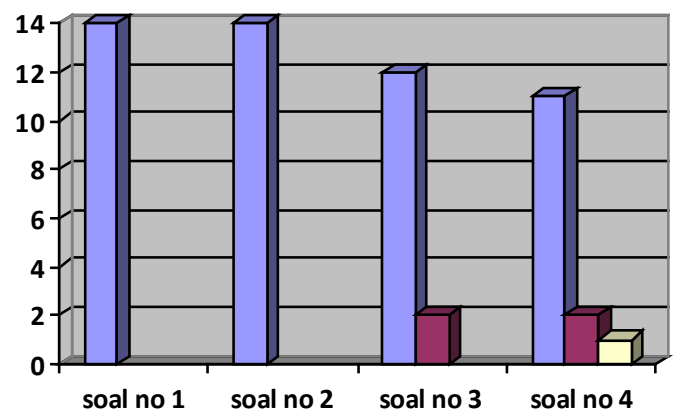

\begin{tabular}{|l|}
\hline mampu menjawab \\
$\square$ menjawab dengan singkat \\
$\square$ jawaban salah
\end{tabular}

Gambar 1. Hasil penilaian lembar kerja siswa 
Berdasarkan diagram tersebut diatas, terdapat 4 soal evaluasi dimana disusun berdasarkan kriteria Higher Order Thinking Skill dengan menitikberatkan pada proses analisis, proses evaluasi, dan proses mencipta. Soal-soal HOTS merupakan instrumen pengukuran yang digunakan untuk mengukur kemampuan berpikir tingkat tinggi, yaitu kemampuan berpikir yang tidak sekadar mengingat (recall), menyatakan kembali (restate), atau merujuk tanpa melakukan pengolahan (recite). Soal-soal HOTS pada konteks asesmen mengukur kemampuan: 1) transfer satu konsep ke konsep lainnya, 2) memproses dan menerapkan informasi, 3) mencari kaitan dari berbagai informasi yang berbeda-beda, 4) menggunakan informasi untuk menyelesaikan masalah, dan 5) menelaah ide dan informasi secara kritis (Hanifah, 2019).

Dari keempat soal yang diberikan kepada siswa, untuk soal nomor 1 dan soal nomor 2 semua siswa mampu menjawab sebanyak 14 siswa (100\%). Soal nomor 3 siswa mampu menjawab sebanyak 12 siswa (85\%) dan siswa menjawab dengan singkat sebanyak 2 siswa (15\%). Soal nomor 4 siswa mampu menjawab sebanyak 11 siswa (78\%), menjawab dengan singkat sebanyak 2 siswa (14\%), dan jawaban salah sebanyak 1 siswa (8\%).

Soal nomor 1 dan nomor 2, yang diujikan adalah tentang menganalisis isi teks dalam cerita "Menjaga Kerukunan Dan Kesatuan Dalam Keberagaman". Pada soal ini, siswa diharuskan membaca terlebih dahulu seluruh isi teks cerita tersebut, kemudian setelah itu, siswa diminta untuk menuliskan informasi penting dan ide pokok yang terdapat dalam teks cerita tersebut pada lembar kerja yang sudah disediakan. Semua siswa mampu menjawab dengan tepat sesuai dengan indikator pencapaian hasil belajar yaitu mampu menuliskan informasi penting dan ide pokok yang terdapat dalam teks. Semua siswa dapat menjawab soal nomor 1 dan soal nomor 2 dengan tepat (100\%). Dengan demikian, siswa memiliki kemampuan analisis baik dari aspekaspek materi pembelajaran atau apapun, yang didapat dari proses 
pembelajaran yang diterapkan dalam proses analisis dalam penyelesaian soal penilaian berbasis HOTS.

Soal nomor 3, yang diujikan tentang mengarang dan membuat paragraf utuh berdasrkan informasi penting dan ide pokok yang sudah dibuat pada soal sebelumnya. Masih dengan teks cerita yang sama, siswa diharuskan untuk dapat membuat ringkasan satu paragraf utuh berisi informasi penting dan ide pokok yang terdapat dalam teks cerita. Sebanyak 12 siswa mampu menjawab dengan tepat (85\%), namun ada 2 siswa (15\%) hanya menjawab dengan singkat saja. Pada soal no 3 ini, siswa diharapkan dapat mengambil keputusan sendiri tentang apa yang akan dituangkan dalam jawaban, namun ada 2 siswa yang tidak bisa menjawab dengan tepat, artinya siswa tersebut belum bisa menerapkan proses evaluasi C5 dalam menyelesaikan soal penilaian berbasis HOTS tersebut.

Soal nomor 4, yang diujikan tentang membuat peta pikiran berdasarkan pada teks cerita yang masih sama dengan sebelumnya. Siswa diminta untuk membuat peta pikiran berdasarkan pada jawaban soal nomor 1 dan nomor 2 dengan cara membuat peta pikiran dalam bentuk diagram anak panah. Sebanyak 11 siswa (78\%) mampu menjawab dengan tepat, dan 2 siswa (14\%) menjawab dengan singkat, namun ada satu siswa (8\%) tidak mampu menjawab sehingga jawabannya salah. Dalam permasalahan ini, ada satu siswa yang tidak bisa menjawab dengan tepat pada soal nomor 4, salah satu faktornya adalah kematangan usia siswa tersebut yang seharusnya masih kelas III dari segi usia rata-rata siswa, sehingga mempengaruhi tingkat kognitif siswa tersebut yang tidak bisa menjawab dengan tepat soal penilaian berbasis HOTS. 
Tabel 2. Distribusi soal penilaian HOTS siswa

\begin{tabular}{clc}
\hline Soal Nomor & \multicolumn{1}{c}{ Bentuk pertanyaan dalam soal } & Tingkat kognitif \\
\hline 1 & $\begin{array}{l}\text { Menganalisis dan menemukan informasi } \\
\text { penting yang terdapat dalam teks cerita }\end{array}$ & $\mathrm{C} 4$ \\
\hline 2 & $\begin{array}{l}\text { Menganalisis dan menemukan ide pokok } \\
\text { yang terdapat dalam teks cerita. }\end{array}$ & $\mathrm{C} 4$ \\
\hline 3 & $\begin{array}{l}\text { Membuat sebuah paragraf berdasarkan } \\
\text { teks cerita }\end{array}$ & $\mathrm{C} 5$ \\
\hline 4 & $\begin{array}{l}\text { Membuat peta pikiran berdasarkan teks } \\
\text { cerita }\end{array}$ & $\mathrm{C} 6$ \\
\hline
\end{tabular}

Berdasarkan hasil penelitian ini, mengenai analisis kemampuan HOTS siswa menggunakan penilaian dengan soal-soal HOTS dapat mengetahui keterampilan berpikir siswa khususnya keterampilan berpikir tingkat tinggi. Dengan pemberian penilaian berbasis HOTS semacam ini, ternyata mampu melihat kemampuan setiap peserta didik, sehingga mampu meningkatkan kemahiran peserta didik dalam mengolah keterampilan berpikir tingkat tingginya, dari memahami secara konseptual hingga mampu menganalisis bahkan sampai mencipta dimana kriteria-kriteria tersebut merupakan kriteria berpikir tingkat tinggi (HOTS).

\section{Problematika Penerapan}

Setelah melakukan proses analisis penilaian hasil belajar peserta didik, ada beberapa faktor yang mempengaruhi hasil belajar siswa. Secara garis besar, yang pertama mempengaruhi hasil belajar siswa adalah cara berpikir yang dilalui oleh peserta didik, namun ada dua faktor besar yang mempengaruhi hasil belajar peserta didik, yaitu faktor internal dan faktor eksternal peserta didik.

Faktor-faktor inilah yang sangat berpengaruh dalam hasil belajar peserta didik. Jika mungkin selama ini guru dan bahkan orang tua hanya menyuruh muridnya atau anaknya untuk belajar dan belajar, tanpa memberikan penjelasan atau alasan kenapa kita harus belajar. Tentunya proses-proses inilah yang 
harus diajarkan kepada murid kita, terlebih lagi proses belajar merupakan suatu aktivitas yang begitu kompleks. Diantara dua faktor tersebut,lebih lanjut (Sardiyanah 2015:184-191) yang mempengaruhi hasil belajar peserta didik dapat dibagi menjadi dua yang akan dijelaskan sebagai berikut:

\section{a. Faktor Internal Peserta Didik}

Faktor ini meliputi segala sesuatu yang berhubungan dengan dirinya. faktor tersebut meliputi ciri-ciri fisik dan bentuk tubuh, faktor kesehatan, dan fakktor intelegensi atau kecerdasan. Sehingga dalam permasalahan penelitian di atas menunjukkan bahwa individu peserta didik bertanggungjawab terhadap hasil bejar mereka dalam kaitan menjawab soal evaluasi berbasis HOTS. Peserta didik yang merasa kesulitan, tentunya dari segi fisik usianya memang jauh dari rata-rata peserta didik lainnya di kelas tersebut, selain itu juga faktor intelegensi peserta didik, tentunya dalam memahami soal-soal evaluasi yang memiliki tingkat kesulitan yang tinggi dia akan merasakan kesulitan, dengan konsekuensi tidak tuntasnya dalam menyelesaian soal evaluasi tersebut. Adapun keberhasilan hasil tes yang didapat oleh peserta didik lain menandakan bahwa faktor internal sangat mendukung, sehingga peserta didik tersebut dapat menyelesaikan soal evaluasi dengan tepat.

\section{b. Faktor Eksternal Peserta Didik}

Faktor eksternal ini meliputi faktor lingkungan keluarga, faktor lingkungan, dan faktor lingkungan sekolah. Dimana kita tahu bahwa keluarga adalah pokok dari karakter anak, ia akan baik bila dididik dengan cara yang baik. Selain itu, sekolah sebagai lembaga pendidikan formal juga berperan penting dalam keberhasilan belajar anak, bila sekolah tersebut mampu menyediakan apa yang dibutuhkan oleh anak tersebut untuk mencapai keberhasilan belajar peserta didik pada lembaga pendidikan formal. Faktor lainnya yaitu 
lingkungan masyarakat. Apabila sudah dididik di lingkungan keluarga yang baik ditambah dilingkungan sekolah juga sangat mendukung untuk melakukan proses belajar, namun apabila faktor lingkungan masyarakat tidak mendukung bisa jadi kesemuanya bisa tidak berjalan dengan maksimal.

Diluar kedua faktor tersebut di atas, guru juga sangat berperan penting dalam keberhasilan pembelajaran. Mulai dari menyiapkan pembelajaran hingga menyiapkan bahan evaluasi pembelajaran, hingga menghasilkan peserta didik dengan yang benar-benar menguasai materi pembelajaran. Guru ketika menyiapkan soal evaluasi pembelajaran berbasis keterampilan berpikir tingkat tinggi, maka hasil yang didapat adalah peserta didik yang mampu berpikir dan memecahkan masalah dengan memanfaatkan kemampuan berpikir yang diberikan oleh gurunya yang kemudian diaplikasikan dalam penyelesaian soal evaluasi bahkan sampai pada penyelesaian masalah-masalah dalam kehidupan sehari-hari.

\section{Kesimpulan}

Berdasarkan hasil analisis dan pembahasan, penelitian ini secara keseluruhan disimpulkan bahwa menerapkan isntrumen evaluasi kepada peserta didik berbasis keterampilan berpikir tingkat tinggi mampu mengoptimalkan hasil belajar peserta didik dan menghasilkan peserta didik memiliki ranah kognitif yang sudah memenuhi kriteria keterampilan berpikir tingkat tinggi. Adapun yang belum mencapai kriteria HOTS terjadi dikarenakan belum matangnya kesiapan peserta didik dari segi usia dan kemampuan kognitifnya, sehingga perlu ditingkatkan lagi dengan menguatkan pemahaman peserta didik pada keterampilan berpikir tingkat tinggi pada level C4, C5, dan C6 agar lebih merata dan menghasilkan pemahaman HOTS terhadap semua peserta didik. 


\section{DAFTAR PUSTAKA}

Anderson, Lorin W.. Karthwohl, D. R. (2014). Kerangka Landasan Untuk Pembelajaran, Pengajaran, dan Asesmen Revisi Taksonomi Pendidikan Bloom. Pustaka Pelajar.

DIKDAS, G. (2019). Pengembangan Pembelajaran Berorientasi HOTS. Pgdikdas.Kemdikbud.Go.Id.

Djiwandono, S. (2011). Tes Bahasa: Pegangan bagi Pengajar Bahasa (Edisi 2). Indeks.

Hamzah, A. (2019). Metode Penelitian Kepustakaan (Library Research) Kajian Filosofis, Teoritis, dan Aplikatif. Literasi Nusantara.

Hanifah, N. (2019). Pengembangan instrumen penilaian Higher Order Thinking Skill ( HOTS ) di sekolah dasar. Conference Series, 1(1), 1-8.

Helmawati. (2019). Pembelajaran dan Penilaian Berbasis HOTS. PT Remaja Rosdakarya.

Khotimah, K. (2019). Pengembangan Evaluasi Pembelajaran berbasis Higher Order Thinking Skill di Sekolah Dasar. Prosiding Seminar Nasional Pendidikan, 1(1), 87-89.

Kunandar. (2014). Penilaian Autentik (Penilaian Hasil Belajar Peserta Didik Berdasarkan Kurikulum 2013. Raja Grafindo Persada.

Lubis, A. M. (2019). Pembelajaran Tematik SD/MI Implementasi Kurikulum 2013 Berbasis HOTS (Higher Order Thinking Skills. Samudra Biru.

Mubarok, H. (2019). High Order Thinking Skill dalam Pembentukan Karakter Siswa Sekolah Dasar di Era Industri 4.0. ELEMENTARY: Islamic Teacher Journal, 7(2), 215. https://doi.org/10.21043/elementary.v7i2.6107

Nahrowi, M. (2019). Pengembangan Model Penilaian Autentik dalam Pembelajaran Tematik Berbasis Higher Order 
Thinking Skill (HOTS) pada Madrasah Ibtidaiyah di Kecamatan Gebog Kabupaten Kudus. ELEMENTARY: Islamic Teacher Journal, 7(2), 279. https://doi.org/10.21043/ elementary.v7i2.6005.

Nugroho, R. A. (2019). HOTS (Kemampuan Berpikir Tingkat Tinggi: Konsep, Pembelajaran, Penilaian, dan Soal-Soal). Konpas Gramedia.

Salsabilla, S., \& Zafi, A. A. (2020). Kecerdasan Interpersonal Peserta Didik Sekolah Dasar. Jurnal Pendidikan Dan Pembelajaran Dasar, 7(1), 35-42. http://ejournal.radenintan.ac.id/index. php/terampil/index.

Sardiyanah. (2015). Belajar dan Faktor Yang Mempengaruhinya. $7(1), 174-196$.

Suyomukti, N. (2013). Teori-Teori Pendidikan Tradisional, (Neo) Liberal, Marxis-Sosialis, Postmodern. Ar-Ruzz Media.

Taubah, M. (2019). Penilaian HOTS dan Penerapannya di SD/MI. ELEMENTARY: Islamic Teacher Journal, 7(2), 197. https:// doi.org/10.21043/elementary.v7i2.6368

Zafi, A. A. (2020). Pemahaman dan Penghayatan Peserta Didik tentang Ibadah dalam Pembelajaran Fiqih di MI Manafiul Ulum Gebog Kudus. Elementary: Jurnal Ilmiah Pendidikan Dasar, 6(1), 47-58. https://doi.org/10.32332/ ELEMENTARY.V6I1.1692. 
396 | Untung Setyo Aji

Elementary Vol. 8 No. 2 Juli - Desember 2020 